Article

\title{
Synthesis, X-ray Structure, Antimicrobial and Anticancer Activity of a Novel [Ag(ethyl-3-quinolate) ${ }_{2}$ (citrate)] Complex
}

\author{
Mezna Saleh Altowyan ${ }^{1}\left(\mathbb{D}\right.$, Mostafa A. El-Naggar ${ }^{2, *}$, Morsy A. M. Abu-Youssef ${ }^{2}$, Saied M. Soliman ${ }^{2, *(\mathbb{})}$ \\ Matti Haukka $\left.{ }^{3}{ }^{(}\right)$, Assem Barakat ${ }^{4}\left(\mathbb{D}\right.$ and Ahmed M. A. Badr ${ }^{2, *}$ \\ 1 Department of Chemistry, College of Science, Princess Nourah bint Abdulrahman University, P.O. Box 84428, \\ Riyadh 11671, Saudi Arabia; msaltowyan@pnu.edu.sa \\ 2 Department of Chemistry, Faculty of Science, Alexandria University, P.O. Box 426, Ibrahimia, \\ Alexandria 21321, Egypt; morsy5@alexu.edu.eg \\ 3 Department of Chemistry, University of Jyväskylä, P.O. Box 35, FI-40014 Jyväskylä, Finland; \\ matti.o.haukka@jyu.fi \\ 4 Department of Chemistry, College of Science, King Saud University, P.O. Box 2455, \\ Riyadh 11451, Saudi Arabia; ambarakat@ksu.edu.sa \\ * Correspondence: mostafa.elnaggar@alexu.edu.eg (M.A.E.-N.); saied1soliman@yahoo.com (S.M.S.); \\ ahmed_badr@alexu.edu.eg (A.M.A.B.); Tel.: +20-1012463029 (M.A.E.-N.); +20-1005002949 (A.M.A.B.)
}

Citation: Altowyan, M.S.; El-Naggar, M.A.; Abu-Youssef,

M.A.M.; Soliman, S.M.; Haukka, M.;

Barakat, A.; Badr, A.M.A. Synthesis, $X$-ray Structure, Antimicrobial and Anticancer Activity of a Novel [Ag(ethyl-3-quinolate) ${ }_{2}$ (citrate)] Complex. Crystals 2022, 12, 356.

https://doi.org/10.3390/

cryst12030356

Academic Editor: Ana

M. Garcia-Deibe

Received: 19 February 2022

Accepted: 3 March 2022

Published: 7 March 2022

Publisher's Note: MDPI stays neutral with regard to jurisdictional claims in published maps and institutional affiliations.

Copyright: (C) 2022 by the authors. Licensee MDPI, Basel, Switzerland. This article is an open access article distributed under the terms and conditions of the Creative Commons Attribution (CC BY) license (https:// creativecommons.org/licenses/by/ $4.0 /)$.

\begin{abstract}
A novel Ag(I) citrate complex with ethyl-3-quinolate (Et3qu) was synthesized. Its structure was confirmed using X-ray single crystal to be $\left[\mathbf{A g}(\mathbf{E t} \mathbf{3 q u})_{2}\right.$ (citrate)]. It crystallized in the Triclinic crystal system and P-1 space group with unit cell parameters of $a=8.6475(2) \AA, b=11.4426(3) \AA$, $c=15.2256(3) \AA, \alpha=73.636(2)^{\circ}, \beta=79.692(2)^{\circ}$ and $\gamma=86.832(2)^{\circ}$, while the unit cell volume was

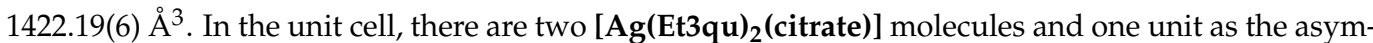
metric formula. The molecular structure comprised one $\mathrm{Ag}(\mathrm{I})$ coordinated with two Et3qu molecules via two almost equidistant $\mathrm{Ag}-\mathrm{N}$ bonds and one citrate ion acting as a mono-negative monodentate ligand via a short Ag-O bond (2.5401(14) $\AA$ ). Hence, $\mathrm{Ag}(\mathrm{I})$ is tri-coordinated and has a highly distorted triangular planar coordination geometry which is more like to be described as a slightly distorted T-shape. The supramolecular structure of the $\left[\mathbf{A g}(\mathbf{E t} \mathbf{3 q u})_{\mathbf{2}}\right.$ (citrate)] complex was analyzed using Hirshfeld calculations. The $\mathrm{H} \cdots \mathrm{H}(39.3-40.1 \%), \mathrm{O} \cdots \mathrm{H}(33.2-34.0 \%), \mathrm{C} \cdots \mathrm{C}(9.1-9.5 \%)$ and $\mathrm{C} \cdots \mathrm{H}(7.2-7.4 \%)$ contacts shared significantly in the packing of the studied $\mathrm{Ag}(\mathrm{I})$ complex. The antimicrobial and anticancer activities of the $\mathrm{Ag}(\mathrm{I})$ complex were investigated. The $\left[\mathbf{A g}\left(\mathbf{E t} \mathbf{3 q u} \mathbf{~}_{\mathbf{2}}\right.\right.$ (citrate)] complex has broad-spectrum antimicrobial activity specifically against the fungus $A$. fumigatus. In addition, the $\mathrm{IC}_{50}$ values of $1.87 \pm 0.09 \mu \mathrm{g} / \mathrm{mL}$ and $0.95 \pm 0.06 \mu \mathrm{g} / \mathrm{mL}$ against the breast MCF-7 and lung A-549 cell lines, respectively, revealed the potent anticancer activity of the $\left[\mathbf{A g}(\mathbf{E t} \mathbf{3 q u})_{2}\right.$ (citrate)] complex compared to the free Et3qu ( $\mathrm{IC}_{50}=30.64 \pm 1.98$ and $22.89 \pm 1.48 \mu \mathrm{g} / \mathrm{mL}$, respectively).
\end{abstract}

Keywords: Hirshfeld; X-ray; antimicrobial; anticancer; Ag/quinoline/citrate complex

\section{Introduction}

Silver(I) complexes have gotten a lot of attention because of their pharmacological and biological characteristics, which makes them promising antibacterial and antifungal agents [1-4]. Cisplatin, as well as its derivatives, has been the most widely applied metalbased drug in cancer treatment. Their mechanisms of action are recognized by their interactions with DNA. However, their use is restricted due to potential side effects, toxicity, and acquired drug resistance [5,6]. To avoid the drawbacks of cisplatin, researchers have looked into a new class of metal-based drugs that are less poisonous and more efficient in chemotherapy for inhibiting the growth of human tumor cell lines, as well as harmful microbes. In recent decades, $\mathrm{Ag}(\mathrm{I})$ has also gained popularity as an anticancer therapeutic. A set of literature reviews discussed silver(I) complexes with various types of ligands, 
including amino acids, nitrogen, carboxylic acids, sulfur or phosphorus donor ligands, that have specific effects against a range of various tumor cells [7-9].

Numerous silver(I) complexes, especially those containing N-heterocyclic ligands, have demonstrated great cytotoxicity against a variety of mammalian cancer cells [10]. The development of new, simple, inexpensive and safe silver complexes containing bioactive ligands is a needed target from researchers. In order to improve and gain better biological drugs, mixed ligands have been applied in the coordination process with $\mathrm{Ag}(\mathrm{I})$ ions. In general, mixed-ligand complexes have demonstrated greater biological properties than the corresponding mono-ligand complexes. Since these complexes have so many functional groups and binding sites, they can be used in a variety of ways in drugs and the pharmaceutical industry. In addition, mixed-ligand complexes provide a better understanding of biological systems in which mixed chelation is the most common type of bonding. Furthermore, different ligand combinations will produce a wide range of physical and chemical features $[11,12]$. The study of silver(I) carboxylates is yet another important contributor to the development of new medications [13-15]. Silver citrate in combination with $\mathrm{N}$-heterocycles is thought to be very appealing for future therapeutic, biomedical or pharmaceutical applications. According to a review of the literature, these complexes are likely to act synergistically as enhancers of antimicrobial activity, antioxidants and anticancer agents [16-19]. As a result, we are interested in synthesizing a new $\mathrm{Ag}(\mathrm{I})$ complex with mixed bioactive ligands, ethyl-3-quinolate and citric acid (Figure 1), in search of a more effective multipurpose compound that can be used as both an anticancer and antimicrobial agent. This study presents the synthesis and X-ray crystal structure of a novel $\mathrm{Ag}(\mathrm{I})$ citrate complex. Additionally, the antimicrobial and anticancer activities of the $\mathrm{Ag}(\mathrm{I})$ complex were investigated.

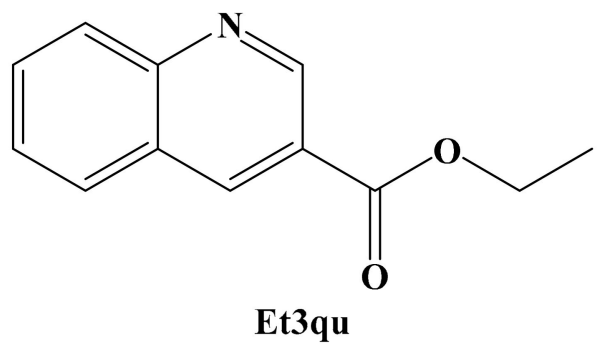<smiles>O=C(O)CC(O)(CC(=O)O)C(=O)O</smiles>

Figure 1. Structures of the studied ligands.

\section{Materials and Methods}

\subsection{Physicochemical Characterizations}

Chemicals used were purchased from Sigma-Aldrich. The FTIR analysis was performed at $4000-400 \mathrm{~cm}^{-1}$ in $\mathrm{KBr}$ pellets by Bruker Tensor 37 FTIR equipment, Waltham, MA, USA. A Perkin Elmer 2400 Elemental Analyzer was utilized to perform the CHN analysis (PerkinElmer, Inc., 940 Winter Street, Waltham, MA, USA). A Shimadzu atomic absorption spectrophotometer (AA-7000 series, Shimadzu, Ltd., Kyoto, Japan) was used to measure the Ag content.

\subsection{Synthesis of $\left[\mathrm{Ag}(\mathrm{Et} 3 q u)_{2}\right.$ (citrate) $]$}

Silver citrate can be properly synthesized by the method mentioned in the literature [16]. Since it has a limited solubility in water [16], silver citrate (299 $\mathrm{mg}, 1 \mathrm{mmol})$ was dissolved in a 5-mL aqueous solution of citric acid ( $20 \mathrm{mg}, 0.1 \mathrm{mmol})$, then mixed with two equivalents of ethyl quinoline-3-carboxylate ( $402 \mathrm{mg}, 2 \mathrm{mmol}$ ) in $10 \mathrm{~mL}$ of ethanol. The mixture was stirred for few minutes while it warmed. The solution was filtered, and the clear filtrate was kept at room temperature. After one week, colorless crystals suitable for $X$-ray diffraction were isolated and air dried.

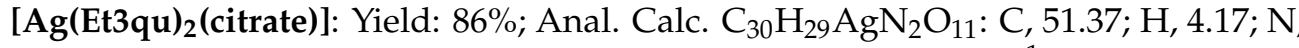
3.99; Ag, 15.38\%. Found: C, 51.22; H, 4.21; N, 3.25; Ag, 15.41\%. FTIR cm ${ }^{-1}: 3429,3059,2990$, 
$1718,1617,1597,1577,1528,1503,1373,1338,1290,1243,1199,1020,790,585,524,492,442$ (Figure S1, Supplementary Data). Ligand (Et3qu): 3046, 2978, 1711, 1617, 1569, 1423, 1373, 1294, 1245, 1197, 1097, 1018, 973, 477 (Figure S2, Supplementary Data).

\subsection{Biological Studies}

The antimicrobial [20] and anticancer [21] activities of Et3qu and its Ag(I) complex were determined as described in Methods S1 and S2 (Supplementary Data).

\subsection{Crystal Structure Determination}

The crystal structure measurements and solution details of [Ag(Et3qu)2(citrate)] are depicted in the Supplementary Data [22-25]. The crystallographic details are summarized in Table 1. The topology analyses were performed using the Crystal Explorer 17.5 program [26].

Table 1. Crystal data of [Ag(Et3qu)2(citrate)].

\begin{tabular}{ll}
\hline CCDC & 2151811 \\
empirical formula & $\mathrm{C}_{30} \mathrm{H}_{29} \mathrm{AgN}_{2} \mathrm{O}_{11}$ \\
fw & 701.42 \\
temp $(\mathrm{K})$ & $120(2) \mathrm{K}$ \\
$\lambda(\AA)$ & $1.54184 \AA$ \\
crystal system & Triclinic \\
space group & $\mathrm{P}-1$ \\
$a(\AA)$ & $a=8.6475(2) \AA$ \\
$b(\AA)$ & $b=11.4426(3) \AA$ \\
$c(\AA)$ & $c=15.2256(3) \AA$ \\
$\alpha($ deg $)$ & $73.636(2)^{\circ}$ \\
$\beta($ deg $)$ & $79.692(2)^{\circ}$ \\
$\gamma($ deg $)$ & $86.832(2)^{\circ}$ \\
$V\left(\AA^{3}\right)$ & $1422.19(6) \AA^{3}$ \\
$Z$ & 2 \\
$\rho_{\text {calc }}\left(\mathrm{Mg} / \mathrm{m}^{3}\right)$ & $1.638 \mathrm{Mg}^{3} / \mathrm{m}^{3}$ \\
$\mu(\mathrm{Mo} \mathrm{K} \alpha)\left(\mathrm{mm}^{-1}\right)$ & $6.273 \mathrm{~mm}^{-1}$ \\
No. reflns & 39671 \\
Unique reflns & 5968 \\
Completeness to $\theta=67.684^{\circ}$ & $99.9 \%$ \\
GOOF $\left(F^{2}\right)$ & 1.068 \\
$R_{\text {int }}$ & 0.0295 \\
$R 1^{\mathrm{a}}(\mathrm{I} \geq 2 \sigma)$ & 0.0236 \\
$w R_{2}{ }^{\mathrm{b}}(\mathrm{I} \geq 2 \sigma)$ & 0.0597 \\
\hline$R_{1}=\Sigma|| F_{\mathrm{o}}|-| F_{\mathrm{c}}|| / \Sigma\left|F_{\mathrm{o}}\right| .^{\mathrm{b}} w R_{2}=\left\{\Sigma\left[w\left(F_{\mathrm{o}}{ }^{2}-F_{\mathrm{c}}{ }^{2}\right)^{2}\right] / \Sigma\left[w\left(F_{\mathrm{o}}{ }^{2}\right)^{2}\right]\right\}^{1 / 2}$. \\
\end{tabular}

\section{Results and Discussion}

\subsection{Crystal Structure Description}

The structure of the $\left[\mathbf{A g}(\mathbf{E t} \mathbf{3 q u})_{2}\right.$ (citrate)] complex was unambiguously determined using an X-ray single crystal structure. The structure of the asymmetric unit is presented in Figure 2. This silver(I) complex crystallized in the Triclinic crystal system and P-1 space group. The unit cell parameters are $a=8.6475(2) \AA, b=11.4426(3) \AA, c=15.2256(3) \AA$, $\alpha=73.636(2)^{\circ}, \beta=79.692(2)^{\circ}$ and $\gamma=86.832(2)^{\circ}$. The unit cell volume is $1422.19(6) \AA^{3}$, and the number of molecules per unit cell is two. The structure comprised disorder at the ethyl groups of the ester group in both Et3qu ligand units. Such a situation led to some different orientations for the conformation of the ethyl groups in the coordinated Et $\mathbf{3 q u}$, as shown in the lower part of Figure 2. Furthermore, the $\mathrm{Ag}(\mathrm{I})$ is coordinated with two Et3qu molecules as monodentate ligands, where both Et3qu units are located syn to one another. The two Ag-N bond distances differ marginally from each other, where the Ag1-N1 and Ag1-N2 distances are 2.1818(14) and 2.1848(14) $\AA$, respectively. In addition, the Ag(I) is coordinated with one oxygen atom from the central carboxylate group of the citrate anion 
with a Ag1-O6 bond distance of 2.5401(14) $\AA$. The Ag-N distances are comparable with those found in the structurally related $\mathrm{Ag}(\mathrm{I})$ complexes with quinoline-type ligands [27]. For example, the Ag-N distances in [Ag(6-quinolinecarboxylic acid $\left.)_{2}\right] \mathrm{NO}_{3}$ are found to be 2.1597(15) and 2.1680(15) $\AA$, respectively. The Ag-O distances showed wide variations depending on the structure of the organic ligand [27]. The N1-Ag1-N2 angle is found bent $\left(169.29(5)^{\circ}\right)$, possibly due to the presence of some steric hindering between the bulky Et3qu ligand units and the coordinated citrate anion. The Ag1 $\cdots$ O5 distance is significantly long (2.907(1) $\AA$ ). Hence, the citrate anion is acting as a monodentate ligand via O6 as a donor atom. On the other hand, the N2-Ag1-O6 and N1-Ag1-O6 angles are 90.53(5) and 99.90(5) ${ }^{\circ}$, respectively (Table 2). As a result, the coordination environment could be described as a slightly distorted T-shape where the torsion angles C9N1Ag1O6 and C21N1Ag1O6 are 2.81 and $2.85^{\circ}$, respectively. Additionally, the distances between the mean planes of the two quinoline rings and the central Ag atom are only 0.806 and $0.403 \AA$ for the quinoline rings of lower and higher atom numbering, respectively. These results indicate an almost planar AgN2O coordination sphere. In the literature, the T-shaped coinage metal complexes are well-known, but such an arrangement of donor atoms around the metal ion is still uncommon [28-31]. For example, the di-nuclear $\left[\mathrm{Ag}(\text { methylnicotinate })_{2}\left(\mathrm{ClO}_{4}\right)\right]_{2}$ comprised a tri-coordinated $\mathrm{Ag}(\mathrm{I})$ with a T-shaped coordination environment [31]. In this complex, the Ag-N and Ag-O distances are 2.158(2) and 2.752 (3) $\AA$, respectively, while the N-Ag-N and $\mathrm{N}-\mathrm{Ag}-\mathrm{O}$ angles are $171.26(9)$ and $92.76(9)-89.70(9)^{\circ}$, respectively.

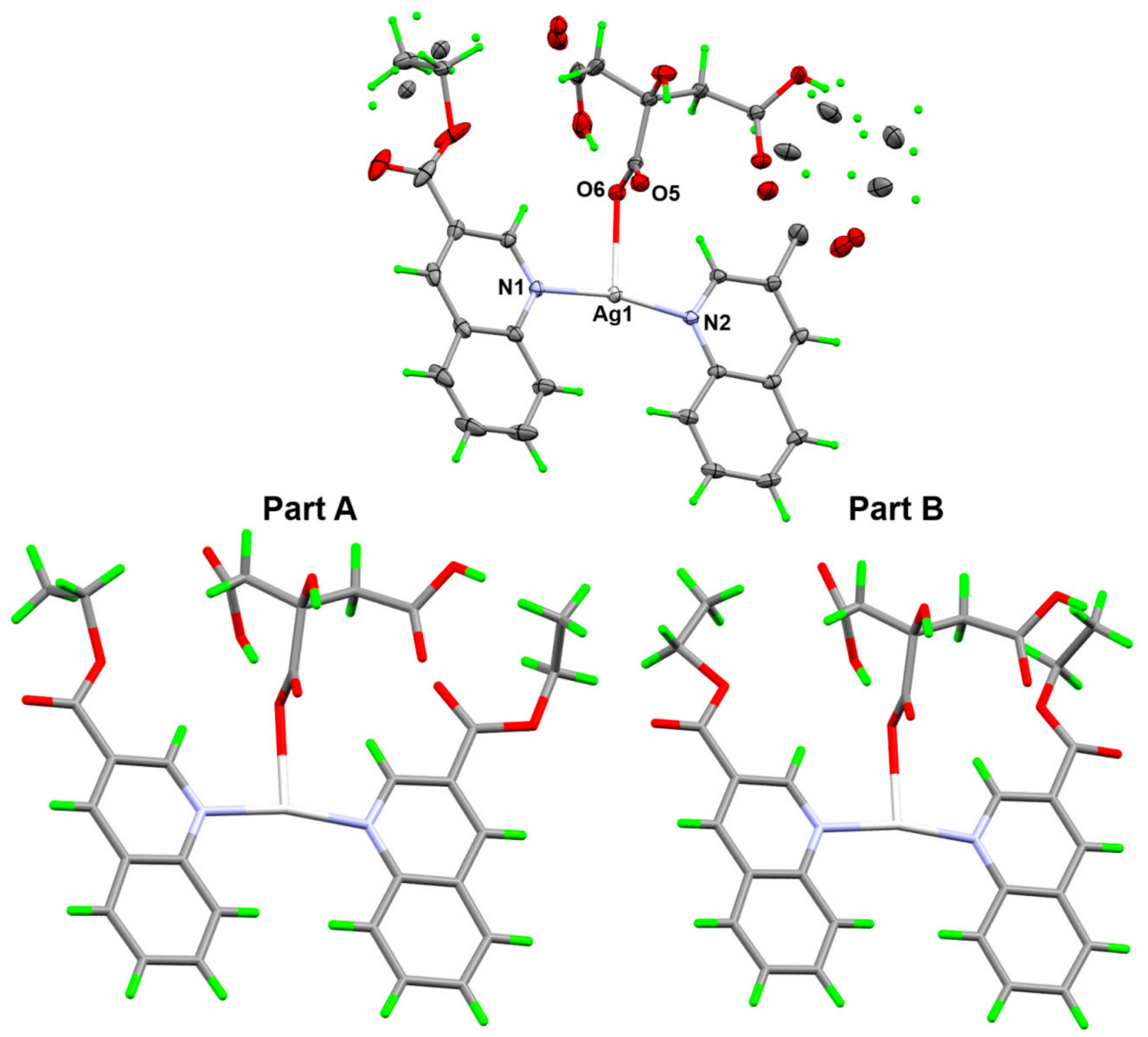

Figure 2. Crystal structure of the $\left[\mathbf{A g}(\mathbf{E t} 3 \mathbf{q u})_{2}\right.$ (citrate)] complex. The structure showed some disorder at the ethyl groups of the ester moieties in the coordinated Et3qu ligand units. 
Table 2. Bond lengths $(\AA)$ and angles $\left(^{\circ}\right)$ for the $[\mathbf{A g}(\mathbf{E t} \mathbf{3 q u}) 2$ (citrate)] complex.

\begin{tabular}{cccc}
\hline Bond & Distance & Bonds & Angle \\
\hline $\operatorname{Ag}(1)-\mathrm{N}(2)$ & $2.1818(14)$ & $\mathrm{N}(2)-\operatorname{Ag}(1)-\mathrm{N}(1)$ & $169.29(5)$ \\
$\operatorname{Ag}(1)-\mathrm{N}(1)$ & $2.1848(14)$ & $\mathrm{N}(2)-\mathrm{Ag}(1)-\mathrm{O}(6)$ & $90.53(5)$ \\
$\operatorname{Ag}(1)-\mathrm{O}(6)$ & $2.5401(14)$ & $\mathrm{N}(1)-\operatorname{Ag}(1)-\mathrm{O}(6)$ & $99.90(5)$ \\
\hline
\end{tabular}

The structure of the $\left[\mathbf{A g}(\mathbf{E t} \mathbf{3 q u})_{\mathbf{2}}\right.$ (citrate)] complex was found to be stabilized by three intramolecular $\mathrm{H} \cdots \mathrm{O}$ contacts, where the two $\mathrm{C} 21-\mathrm{H} 21 \cdots \mathrm{O} 6$ and $\mathrm{O} 7-\mathrm{H} 7 \cdots \mathrm{O} 5$ interactions are common in the two disordered parts shown in Figure 2. The donor-acceptor distances of these interactions are 3.151(2) and 2.593(2) $\AA$, respectively. Additionally, part B comprised another intramolecular interaction (C24B-H24E $\cdots \mathrm{O} 10)$, with a donor-acceptor distance of 3.352(6) A. The different intramolecular and intermolecular $\mathrm{H}$... O interactions present in the structure of the $\left[\mathbf{A g}(\mathbf{E t} \mathbf{3 q u})_{2}\right.$ (citrate)] complex are depicted in the left part of Figure 3, while the right part of the same figure presents the packing view of the complex unit via $\mathrm{O} 10-\mathrm{H} 10 \cdots \mathrm{O} 8$ and $\mathrm{O} 10-\mathrm{H} 10 \cdots \mathrm{O} 8 \mathrm{~B}$ intermolecular interactions found in parts A and $\mathbf{B}$, respectively. The donor-acceptor distances of these hydrogen-bonding interactions are 2.798(18) and 2.569(7) ^, respectively (Table 3).
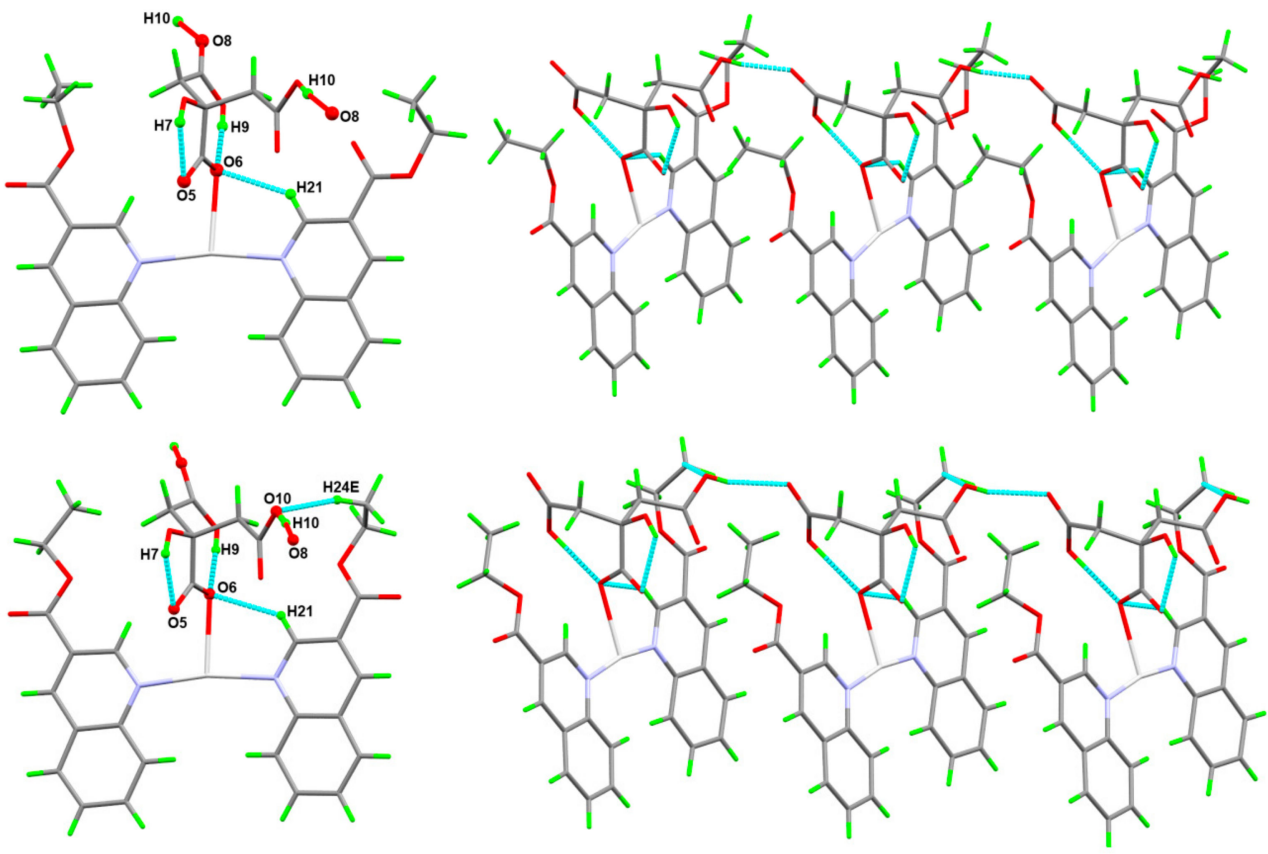

Figure 3. Hydrogen bond contacts (left), and view of the hydrogen bond packing scheme (right) of part A (upper).

Table 3. Hydrogen bond parameters $\left(\AA^{\circ},{ }^{\circ}\right.$ in the $\left[\mathbf{A g}(\text { Et3qu })_{2}\right.$ (citrate) $]$ complex.

\begin{tabular}{ccccc}
\hline $\mathbf{D}-\mathbf{H} \cdots \mathbf{A}$ & $\mathbf{d}(\mathbf{D}-\mathbf{H})$ & $\mathbf{d}(\mathbf{H} \cdots \mathbf{A})$ & $\mathbf{d}(\mathbf{D} \cdots \mathbf{A})$ & $<(\mathbf{D}-\mathbf{H} \cdots \mathbf{A})$ \\
\hline $\mathrm{C}(21)-\mathrm{H}(21) \cdots \mathrm{O}(6)$ & 0.95 & 2.39 & $3.151(2)$ & 137 \\
$\mathrm{O}(10)-\mathrm{H}(10) \cdots \mathrm{O}(8 \mathrm{~B}) \# 1$ & $0.75(3)$ & $2.10(4)$ & $2.798(18)$ & $155(3)$ \\
$\mathrm{O}(10)-\mathrm{H}(10) \cdots \mathrm{O}(8)$ & $0.75(3)$ & $1.83(4)$ & $2.569(7)$ & $170(4)$ \\
$\mathrm{C}(24 \mathrm{~B})-\mathrm{H}(24 \mathrm{E}) \cdots \mathrm{O}(10)$ & 0.98 & 2.44 & $3.352(6)$ & 155.3 \\
$\mathrm{O}(7)-\mathrm{H}(7) \cdots \mathrm{O}(5)$ & $0.77(3)$ & $2.05(3)$ & $2.593(2)$ & $127(3)$ \\
$\mathrm{O}(9)-\mathrm{H}(9)-\mathrm{O}(6)$ & $0.78(4)$ & $1.72(4)$ & $2.499(2)$ & $176(4)$ \\
\hline$\# 1 \mathrm{x})$
\end{tabular}

$\# 1+1, y, z$. 
In addition, there are two significant $\pi-\pi$ stacking interactions between the two quinoline rings (Figure 4). The shortest $\mathrm{C} 14 \cdots \mathrm{C} 18$ contact distance is $3.384 \AA$, and the centroid C18C19C20C21N2C13-to-centroid C13C14C15C16C17C18 distance is $3.659 \AA$.

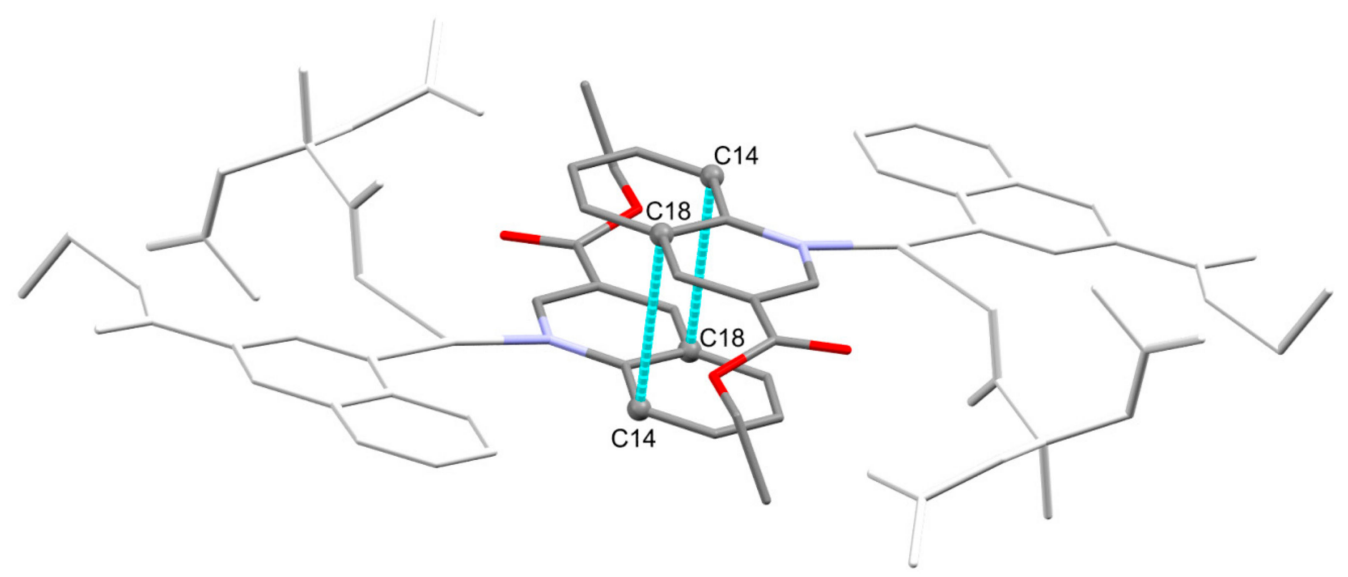

Figure 4. The $\pi-\pi$ stacking interactions in the $\left[\mathbf{A g}(\text { Et3qu })_{2}\right.$ (citrate) $]$ complex.

\subsection{Analysis of Molecular Packing}

The Hirshfeld analysis of the two complex parts $\mathbf{A}$ and $\mathbf{B}$ was used to calculate the percentages of all intermolecular interactions in the crystal structure of the $\left[\mathbf{A g}(\mathbf{E t} 3 \mathbf{q u})_{2}\right.$ (citrate)] complex. The results are depicted in Table 4 and presented in Figure 5. The results indicated that the intermolecular interactions in parts $\mathbf{A}$ and $\mathbf{B}$ are almost the same. The most dominant contacts are the $\mathrm{H} \cdots \mathrm{H}(39.3-40.1 \%)$ and $\mathrm{O} \cdots \mathrm{H}(33.2-34.0 \%)$ interactions. Additionally, the $\mathrm{C} \cdots \mathrm{C}$ and $\mathrm{C} \cdots \mathrm{H}$ contacts shared significantly in the packing of the studied $\mathrm{Ag}(\mathrm{I})$ complex. Their percentages are $9.1-9.5 \%$ and $7.2-7.4 \%$, respectively.

Additionally, the analysis of shape index revealed the presence of red/blue triangles, and the curvedness map showed the flat green area corresponding to the regions included in the $\pi-\pi$ stacking interactions (Figure 6). Additionally, the decomposed fingerprint plot with a characteristic peak for short-distance contacts is considered as evidence of the presence of $\pi-\pi$ stacking interactions.

Table 4. The percentages of all contacts in the $\left[\mathrm{Ag}(\mathrm{Et} 3 \mathrm{qu})_{2}(\mathrm{citrate})\right]$ complex.

\begin{tabular}{ccc}
\hline Contact & A & B \\
\hline $\mathrm{Ag} \cdots \mathrm{Ag}$ & 0.2 & 0.2 \\
$\mathrm{Ag} \cdots \mathrm{N}$ & 0.4 & 0.3 \\
$\mathrm{Ag} \cdots \mathrm{C}$ & 0.3 & 0.4 \\
$\mathrm{Ag} \cdots \mathrm{H}$ & 2.0 & 2.0 \\
$\mathrm{O} \cdots \mathrm{O}$ & 0.5 & 0.5 \\
$\mathrm{C} \cdots \mathrm{O}$ & 2.9 & 3.5 \\
$\mathrm{O} \cdots \mathrm{H}$ & 33.2 & 34.0 \\
$\mathrm{~N} \cdots \mathrm{N}$ & 0.4 & 0.4 \\
$\mathrm{C} \cdots \mathrm{N}$ & 1.9 & 1.9 \\
$\mathrm{~N} \cdots \mathrm{H}$ & 1.2 & 1.2 \\
$\mathrm{C} \cdots \mathrm{C}$ & 9.5 & 9.1 \\
$\mathrm{C} \cdots \mathrm{H}$ & 7.4 & 7.2 \\
$\mathrm{H} \cdots \mathrm{H}$ & 40.1 & 39.3 \\
\hline
\end{tabular}




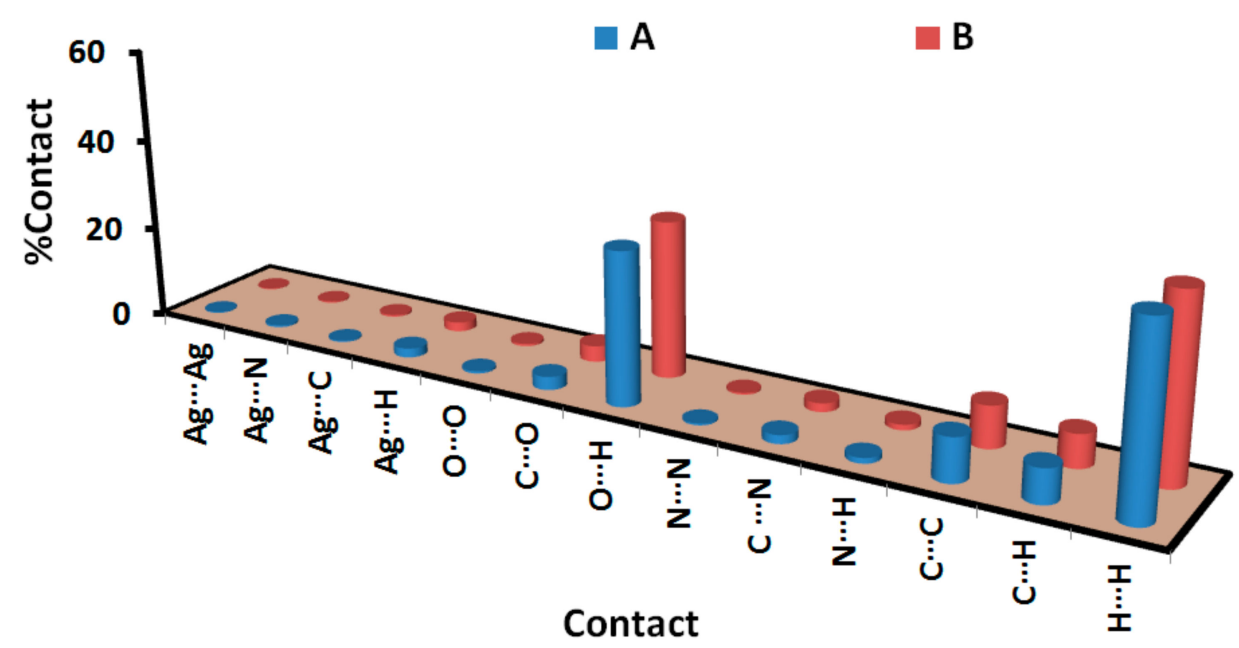

Figure 5. Distribution of the intermolecular interactions in the $\left[\mathrm{Ag}(\mathrm{Et} \mathbf{3 q u})_{2}\right.$ (citrate)] complex. A and $B$ refer to the disorded parts of the $\left[\mathrm{Ag}(\mathrm{Et} 3 \mathbf{q u})_{2}\right.$ (citrate) $]$ complex.
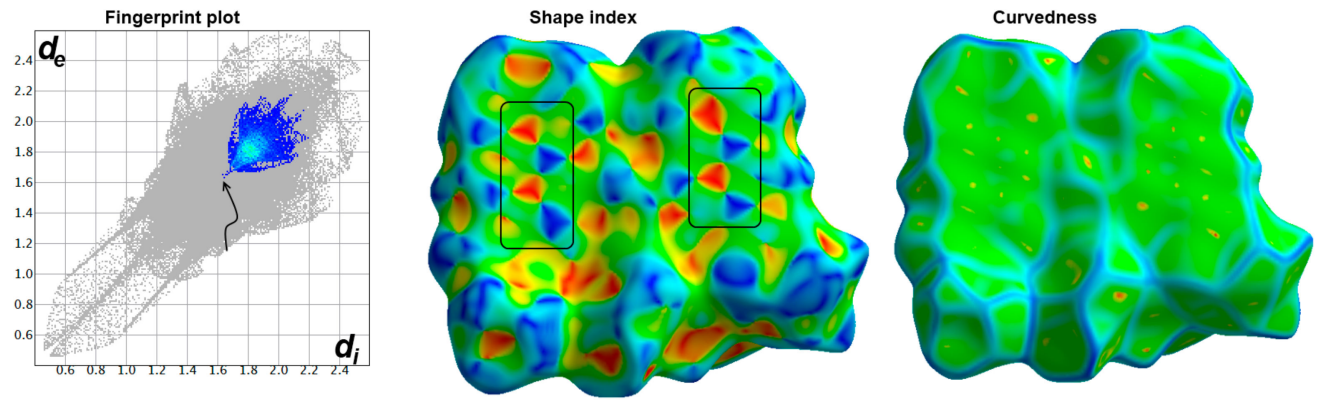

Figure 6. Evidence from the Hirshfeld surfaces on the $\pi-\pi$ stacking interactions in the $\left[\mathrm{Ag}(\mathrm{Et} 3 \mathrm{qu})_{2}\right.$ (citrate)] complex.

\subsection{FTIR Spectra}

The free ligand, Et3qu, exhibits three major absorption bands in its IR spectrum (Figure S2, Supplementary Data). The band at $1710 \mathrm{~cm}^{-1}$ is attributed to the stretching vibration of the $\mathrm{C}=\mathrm{O}$ of the ester group, while the bands at 1617 and $1568 \mathrm{~cm}^{-1}$ correspond to the $v(\mathrm{C}=\mathrm{C})$ and $v(\mathrm{C}=\mathrm{N})$ stretching modes of the quinoline ring, respectively. In the $\mathrm{Ag}(\mathrm{I})$ complex, the corresponding values for $v(\mathrm{C}=\mathrm{O}), v(\mathrm{C}=\mathrm{C})$ and $v(\mathrm{C}=\mathrm{N})$ are 1718,1617 and $1577 \mathrm{~cm}^{-1}$, respectively (Figure S1, Supplementary Data). The observable shift in the position and shape of the $v(\mathrm{C}=\mathrm{N})$ band in $\left[\mathrm{Ag}(\mathrm{Et} \mathbf{3 q u})_{2}\right.$ (citrate)] indicates its direct coordination to the silver center. The noticeable change in the intensity of $v(\mathrm{C}=\mathrm{O})$ of the mixed-ligand complex compared to the free ligand is attributed to the carbonyl group of the coordinated ethyl-3-quinolate and that of citric acid. In addition, the appearance of two new bands in the range 1335-1375 and $1597 \mathrm{~cm}^{-1}$ in the spectrum of the complex can be assigned to the symmetric and asymmetric stretching vibrations of the $\mathrm{COO}^{-}$ group, respectively, indicating a monodentate mode of the citrate group around the $\mathrm{Ag}(\mathrm{I})$ ion [32,33]. Finally, some new moderate-intensity IR bands are observed in the complex spectrum in the regions $480-570$ and $400-460 \mathrm{~cm}^{-1}$. These bands can be assigned to the vibrational modes of $\mathrm{Ag}-\mathrm{O}$ and $\mathrm{Ag}-\mathrm{N}$ bonds, respectively [34].

\subsection{Antimicrobial Studies}

The antimicrobial activity of Et3qu and its [Ag(Et3qu) ${ }_{2}$ (citrate)] complex were determined. The sizes of the inhibition zones for the two compounds at $10 \mathrm{mg} / \mathrm{mL}$ against different microbes are listed in Table 5 . The free ligand showed good antifungal activity against $A$. fumigatus and C. albicans. The inhibition zone diameters were determined to be 
30 and $19 \mathrm{~mm}$, respectively. Additionally, the Et3qu ligand and the [Ag(Et3qu) $\mathbf{2}_{\mathbf{2}}$ (citrate)] complex have similar results against $A$. fumigatus $(30 \mathrm{~mm})$, but the $\mathrm{Ag}(\mathrm{I})$ complex is less active against the fungus $C$. albicans $(15 \mathrm{~mm})$. On the other hand, the $\left[\mathbf{A g}(\mathbf{E t} 3 \mathbf{q u})_{\mathbf{2}}\right.$ (citrate)] complex has good activity against the Gram-positive bacteria $S$. aureus $(13 \mathrm{~mm})$ and $B$. subtilis $(12 \mathrm{~mm})$, while the free Et3qu showed no activity at the applied concentration

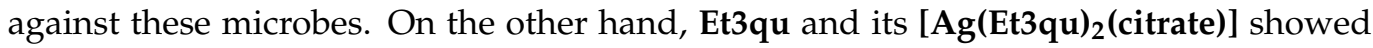
good activity against E. coli and P. vulgaris as Gram-negative bacteria. Both compounds have the same size of inhibition zones for $E$. coli $(12 \mathrm{~mm})$ while the $\mathrm{Ag}(\mathrm{I})$ complex has a larger-size inhibition zone $(18 \mathrm{~mm})$ against $P$. vulgaris than the free Et3qu $(12 \mathrm{~mm})$. In com-

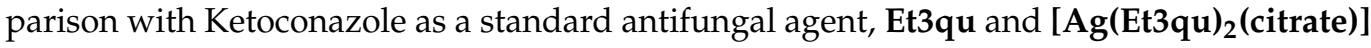
have better activity against $A$. fumigatus. Regarding the antibacterial activity, the $\mathrm{Ag}(\mathrm{I})$ complex has lower sizes of inhibition zones than the standard Gentamycin. The lower antibacterial activity of the $\left[\mathbf{A g}(\mathbf{E t} \mathbf{3 q u})_{2}\right.$ (citrate) $]$ complex compared to Gentamycin indicated that the $\mathrm{Ag}(\mathrm{I})$ complex has broad-spectrum action against both bacteria and fungi, and the MICs results revealed these observations very well. The best MIC results were for both compounds against $A$. fumigatus, where the Ag(I) complex had lower MIC value and better activity than the free Et3qu and the standard Ketoconazole as well. It was believed that the biological action of $\mathrm{Ag}(\mathrm{I})$ complexes depends on the ease of $\mathrm{Ag}(\mathrm{I})$ release to biological fluids. In this regard, silver complexes comprising the relatively weak Ag-N and Ag-O bonds [35] are desirable as antimicrobial agents [36-38].

Table 5. Inhibition zone diameters $(\mathrm{mm})$ and $\mathrm{MIC}(\mu \mathrm{g} / \mathrm{mL})$ values for Et3qu and its [Ag(Et3qu) $\mathbf{2}_{\mathbf{2}}$ (citrate)] complex ${ }^{\mathrm{a}}$.

\begin{tabular}{cccc}
\hline Microbe & Et3qu & [Ag(Et3qu) (citrate) & Control \\
\hline A. fumigatus & $30(9.7)$ & $30(4.8)$ & $17(156.25)^{\mathrm{b}}$ \\
C. albicans & $19(312.5)$ & $15(312.5)$ & $20(312.5)^{\mathrm{b}}$ \\
S. aureus & NA (NA) ${ }^{\mathrm{d}}$ & $13(1250)$ & $24(9.7)^{\mathrm{c}}$ \\
B. subtilis & NA(NA) $\mathrm{d}$ & $12(625)$ & $26(4.8)^{\mathrm{c}}$ \\
E. coli & $12(2500)$ & $12(1250)$ & $30(4.8)^{\mathrm{c}}$ \\
P. vulgaris & $12(2500)$ & $18(1250)$ & $25(4.8)^{\mathrm{c}}$ \\
\hline
\end{tabular}

a MIC values are in parentheses. ${ }^{b}$ Ketoconazole. ${ }^{c}$ Gentamycin. ${ }^{d}$ NA: not active.

\subsection{MTT Assay}

The inhibitory activity against lung (A-549) and breast (MCF-7) carcinoma cells for Et3qu and its [Ag(Et3qu $)_{2}$ (citrate)] complex was determined using the MTT assay (Figure 7). The detailed MTT assay results are given in Tables S1-S4 (Supplementary Data). The results indicated that both compounds showed inhibitory activity against both cell lines, where the $\mathrm{Ag}(\mathrm{I})$ complex has promising anticancer activity. The $\mathrm{IC}_{50}$ values were generally lower for the $\mathrm{Ag}(\mathrm{I})$ complex than the free Et3qu. The $\left[\mathbf{A g}\left(\mathbf{E t} \mathbf{3 q u} \mathbf{2}_{\mathbf{2}}\right.\right.$ (citrate)] had $\mathrm{IC}_{50}$ values of $1.87 \pm 0.09 \mu \mathrm{g} / \mathrm{mL}$ and $0.95 \pm 0.06 \mu \mathrm{g} / \mathrm{mL}$ against the MCF-7 and A-549 cell lines, respectively. The corresponding values for the free Et3qu were $30.64 \pm 1.98$ and $22.89 \pm 1.48 \mu \mathrm{g} / \mathrm{mL}$, respectively. These results indicated the higher anticancer activity of $\left[\mathbf{A g}(\mathbf{E t} 3 \mathbf{q u})_{2}\right.$ (citrate) $]$ compared to the free Et3qu. Additionally, the studied complex exhibited significantly higher cytotoxicity against both cancerous cell lines compared to the reference anticancer drugs doxorubicin and cis-platin (Table 6). It was believed that the interaction between the target compound and DNA via noncovalent interactions could damage the cancer cell, leading to the death of these malignant cells [9]. Recently, the anticancer activity of $\mathrm{Ag}(\mathrm{I})$ complexes was linked to both the metal and coordinating ligand rather than just the metal ions [39,40]. Many factors such as the complex stability and its hydrophilic-lipophilic characters are crucial factors for the anticancer activity of $\mathrm{Ag}(\mathrm{I})$ complexes $[7,40-44]$. 

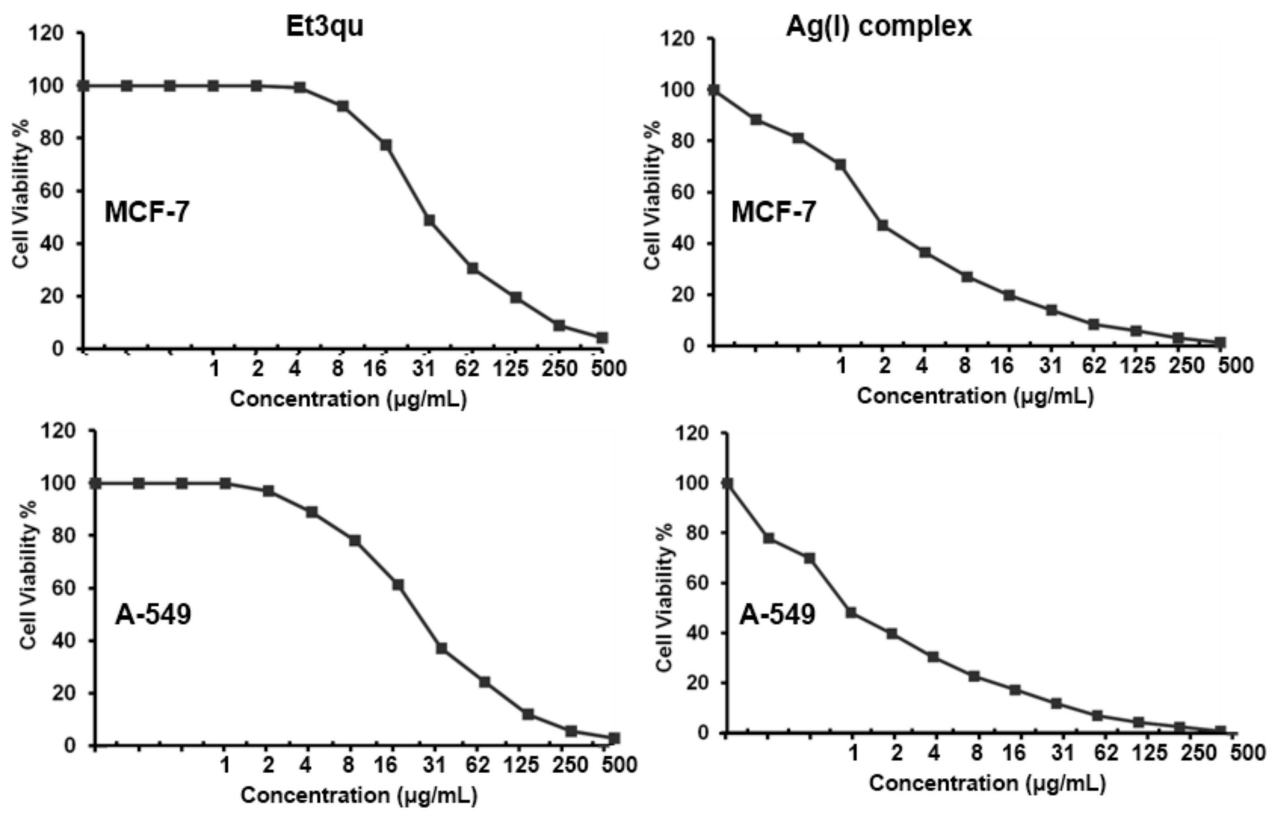

Figure 7. MTT assay of Et3qu and its $\left[\mathrm{Ag}(\mathrm{Et} 3 \mathbf{q u})_{2}\right.$ (citrate) $]$ complex.

Table 6. Anticancer screening (expressed as $\mathrm{IC}_{50}(\mu \mathrm{g} / \mathrm{mL})$ ) of the newly synthesized complex, its corresponding free ligands and the reference drugs against the tested human cancer cell lines.

\begin{tabular}{ccccc}
\hline Cell Line & Cisplatin [45] & Doxorubicin [46] & Et3qu & [Ag(Et3qu)2(citrate)] \\
\hline Lung carcinoma (A-549) & 2.46 & 1.91 & $22.89 \pm 1.48$ & $0.95 \pm 0.06$ \\
Breast carcinoma (MCF-7) & 3.23 & 1.51 & $30.64 \pm 1.98$ & $1.87 \pm 0.09$ \\
\hline
\end{tabular}

\section{Conclusions}

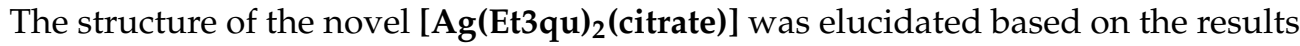
of X-ray single crystal diffraction. It comprised a tri-coordinated Ag(I) with two Et3qu and one citrate as monodentate ligands. The supramolecular structure aspects were analyzed quantitatively using a Hirshfeld analysis. The percentages of the $\mathrm{H} \cdots \mathrm{H}, \mathrm{O} \cdots \mathrm{H}$, C $\cdots$ C and $C \cdots H$ contacts were $39.3-40.1 \%, 33.2-34.0 \%, 9.1-9.5 \%$ and $7.2-7.4 \%$, respectively. Biological experiments indicated promising antimicrobial and anticancer activities of the [Ag(Et3qu $)_{2}$ (citrate)] complex. The results indicated higher anticancer activity of the $\operatorname{Ag}(\mathrm{I})$ complex against the MCF-7 and A-549 cell lines than the free ligand. Additionally, the

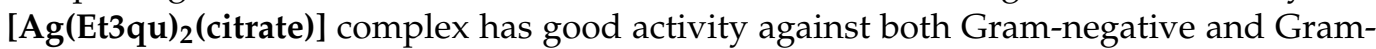
positive bacteria and the fungi as well, while the free Et3qu ligand showed no activity against the Gram-positive bacteria.

Supplementary Materials: The following supporting information can be downloaded at: https:// www.mdpi.com/article/10.3390/cryst12030356/s1, Crystal structure determination details. Method S1: Antimicrobial activity assay. Method S2: Evaluation of the cytotoxic effects against the A-549

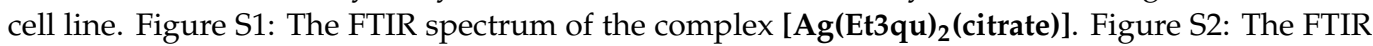
spectrum of the free ligand Et3qu. Table S1: MTT assay for the Ag(I) complex against the MCF-7 cell line. Table S2: MTT assay for Et3qu against the MCF-7 cell line. Table S3: MTT assay for the Ag(I) complex against the A-549 cell line. Table S4: MTT assay for Et3qu against the A-549 cell line.

Author Contributions: Conceptualization, S.M.S. and M.A.M.A.-Y.; methodology, M.A.E.-N., M.H., A.M.A.B. and A.B.; software, S.M.S., M.S.A., A.M.A.B. and A.B.; formal analysis, M.A.E.-N., A.M.A.B. and M.S.A.; investigation, S.M.S., A.M.A.B. and M.A.E.-N.; resources, M.S.A., M.A.M.A.-Y. and A.B.; writing-original draft preparation, S.M.S., M.A.E.-N., M.A.M.A.-Y., A.M.A.B. and A.B.; writingreview and editing, S.M.S., M.A.E.-N., M.A.M.A.-Y., A.M.A.B. and A.B.; supervision, S.M.S. and 
M.A.M.A.-Y.; project administration, M.S.A., A.B., S.M.S. and M.A.M.A.-Y. and funding acquisition, M.S.A. All authors have read and agreed to the published version of the manuscript.

Funding: Princess Nourah bint Abdulrahman University Researchers Supporting Project number (PNURSP2022R86), Princess Nourah bint Abdulrahman University, Riyadh, Saudi Arabia.

Informed Consent Statement: Not applicable.

Data Availability Statement: Not applicable.

Acknowledgments: Princess Nourah bint Abdulrahman University Researchers Supporting Project number (PNURSP2022R86), Princess Nourah bint Abdulrahman University, Riyadh, Saudi Arabia.

Conflicts of Interest: The authors declare no conflict of interest.

\section{References}

1. Nomiya, K.; Takahashi, S.; Noguchi, R.; Nemoto, S.; Takayama, T.; Oda, M. Synthesis and characterization of water-soluble silver(I) complexes with L-histidine $\left(\mathrm{H}_{2}\right.$ his) and (S)-(-)-2-pyrrolidone-5-carboxylic acid $\left(\mathrm{H}_{2}\right.$ pyrrld) showing a wide spectrum of effective antibacterial and antifungal activities. Crystal structures of chiral helical polymers $[\mathrm{Ag}(\mathrm{Hhis})]_{\mathrm{n}}$ and $\left([\mathrm{Ag}(\mathrm{Hpyrrld})]_{2}\right)_{\mathrm{n}}$ in the solid state. Inorg. Chem. 2000, 39, 3301-3311. [PubMed]

2. Özdemir, I.; Demir, S.; Günal, S.; Özdemir, I.; Arici, C.; Ülkü, D. Synthesis, characterization and antimicrobial activity of new silver complexes with $\mathrm{N}$-heterocyclic carbene ligands. Inorg. Chim. Acta 2010, 363, 3803-3808. [CrossRef]

3. Napoli, M.; Saturnino, C.; Cianciulli, E.I.; Varcamontic, M.; Zanfardinoc, A.; Tommonarod, G.; Longoa, P. Silver(I) N-heterocyclic carbene complexes: Synthesis, characterization and antibacterial activity. J. Organomet. Chem. 2013, 725, 46-53. [CrossRef]

4. Smoleński, P.; Jaros, S.W.; Pettinari, C.; Lupidi, G.; Quassinti, L.; Bramucci, M.; Vitali, L.A.; Petrelli, D.; Kochel, A.; Kirillov, A.M. New water-soluble polypyridine silver(I) derivatives of 1,3,5-triaza-7-phosphaadamantane (PTA) with significant antimicrobial and antiproliferative activities. Dalt. Trans. 2013, 42, 6572-6581. [CrossRef] [PubMed]

5. Wu, Z.; Liu, Q.; Liang, X.; Yang, X.; Wang, N.; Wang, X.; Sun, H.; Lu, Y.; Guo, Z. Reactivity of platinum-based antitumor drugs towards a Met- and His-rich 20mer peptide corresponding to the N-terminal domain of human copper transporter 1. J. Biol. Inorg. Chem. 2009, 14, 1313-1323. [CrossRef] [PubMed]

6. Jung, Y.; Lippard, S.J. Direct Cellular Responses to Platinum-Induced DNA Damage. Chem. Rev. 2007, 107, 1387-1407. [CrossRef] [PubMed]

7. Banti, C.N.; Hadjikakou, S.K. Anti-proliferative and anti-tumor activity of silver(I) compounds. Metallomics 2013, 5, 569-596. [CrossRef]

8. Medici, S.; Peana, M.; Nurchi, V.M.; Lachowicz, J.I.; Crisponi, G.; Zoroddu, M.A. Noble metals in medicine: Latest advances Coord. Chem. Rev. 2015, 284, 329-350. [CrossRef]

9. Zaki, M.; Arjmand, F.; Tabassum, S. Current and future potential of metallo drugs: Revisiting DNA-binding of metal containing molecules and their diverse mechanism of action. Inorg. Chim. Acta. 2016, 444, 1-22. [CrossRef]

10. Ortego, L.; Meireles, M.; Kasper, C.; Laguna, A.; Villacampa, M.D.; Gimeno, M.C. Group 11 complexes with amino acid derivatives: Synthesis and antitumoral studies. J. Inorg. Biochem. 2016, 156, 133-144. [CrossRef]

11. Osman, S.A.; Mousa, H.A.; Abdallah, Y.H.A.; Hafez, T.S.; El-Sawy, A.A.; Abdallah, M.M.; Hassan, A.S. Synthesis, characterization and cytotoxicity of mixed ligand $\mathrm{Mn}(\mathrm{II}), \mathrm{Co}(\mathrm{II})$ and $\mathrm{Ni}(\mathrm{II})$ complexes. J. Serbian Chem. Soc. 2014, 79, 953-964. [CrossRef]

12. Jayamani, A.; Bellam, R.; Gopu, G.; Ojwach, S.O.; Sengottuvelan, N. Copper(II) complexes of bidentate mixed ligands as artificial nucleases: Synthesis, crystal structure, characterization and evaluation of biological properties. Polyhedron 2018, 156, 138-149. [CrossRef]

13. Azócar, M.I.; Gómez, G.; Levín, P.; Paez, M.; Muñoz, H.; Dinamarca, N. Review: Antibacterial behavior of carboxylate silver(I) complexes. J. Coord. Chem. 2014, 67, 3840-3853. [CrossRef]

14. Vargová, Z.; Almáši, M.; Hudecová, D.; Titková, D.; Rostášová, I.; Zeleňák, V.; Györyová, K. New silver(I) pyridinecarboxylate complexes: Synthesis, characterization, and antimicrobial therapeutic potential. J. Coord. Chem. 2014, 67, 1002-1021. [CrossRef]

15. Aldabaldetrecu, M.; Tamayo, L.; Alarcon, R.; Walter, M.; Salas-Huenuleo, E.; Kogan, M.J.; Guerrero, J.; Paez, M.; Azócar, M.I. Stability of Antibacterial Silver Carboxylate Complexes against Staphylococcus epidermidis and Their Cytotoxic Effects. Molecules 2018, 23, 1629. [CrossRef] [PubMed]

16. Djokić, S. Synthesis and antimicrobial activity of silver citrate complexes. Bioinorg. Chem. Appl. 2008, 2008, 436458. [CrossRef]

17. Cuin, A.; Massabni, A.C.; Leite, C.Q.F.; Sato, D.N.; Neves, A.; Szpoganicz, B.; Silva, M.S.; Bortoluzzi, A.J. Synthesis, X-ray structure and antimycobacterial activity of silver complexes with alpha-hydroxycarboxylic acids. J. Inorg. Biochem. 2007, 101, 291-296. [CrossRef]

18. Nomiya, K.; Yokoyama, H. Syntheses, crystal structures and antimicrobial activities of polymeric silver(I) complexes with three amino-acids [aspartic acid ( $\mathrm{H}_{2} \mathrm{asp}$ ), glycine (Hgly) and asparagine (Hasn)]. J. Chem. Soc. Dalt. Trans. 2002, 2483-2490. [CrossRef]

19. Batarseh, K.I. Anomaly and correlation of killing in the therapeutic properties of silver (I) chelation with glutamic and tartaric acids. J. Antimicrob. Chemother. 2004, 54, 546-548. [CrossRef]

20. Clinical and Laboratory Standards Institute (CLSI). Twentieth Informational Supplement; M100-S22; CLSI: Wayne, PA, USA, 2012. 
21. Mosmann, T. Rapid colorimetric assay for cellular growth and survival: Application to proliferation and cytotoxicity assays. J. Immunol. Methods 1983, 65, 55-63. [CrossRef]

22. Rikagu Oxford Diffraction. CrysAlisPro; Agilent Technologies Inc.: Santa Clara, CA, USA, 2018.

23. Sheldrick, G.M. SHELXT-Integrated Space-Group and Crystal-Structure Determination. Acta Crystallogr. Sect. A Found. Adv. 2015, 71, 3-8. [CrossRef] [PubMed]

24. Sheldrick, G.M. Crystal Structure Refinement with SHELXL. Acta Crystallogr. Sect. C Struct. Chem. 2015, 71, 3-8. [CrossRef] [PubMed]

25. Hübschle, C.B.; Sheldrick, G.M.; Dittrich, B. ShelXle: A Qt graphical user interface for SHELXL. J. Appl. Crystallogr. 2011, 44, 1281-1284. [CrossRef] [PubMed]

26. Turner, M.J.; McKinnon, J.J.; Wolff, S.K.; Grimwood, D.J.; Spackman, P.R.; Jayatilaka, D.; Spackman, M.A. Crystal Explorer17. 2017. University of Western Australia. Available online: http:/ / hirshfeldsurface.net (accessed on 18 February 2022).

27. Massoud, A.A.; Langer, V.; Gohar, Y.M.; Abu-Youssef, M.A.M.; Janis, J.; Lindberg, G.; Hansson, K.; Ohrstrom, L. Effects of Different Substituents on the Crystal Structures and Antimicrobial Activities of Six Ag(I) Quinoline Compounds. Inorg. Chem. 2013, 52, 4046-4060. [CrossRef]

28. Kleinhans, G.; Chan, A.K.-W.; Leung, M.Y.; Liles, D.C.; Fernandes, M.A.; Yam, V.W.W.; Fernández, I.; Bezuidenhout, D.I. Synthesis and photophysical properties of T-shaped coinage metal complexes. Chem. A Eur. J. 2020, 26, 6993-6998. [CrossRef]

29. Cabeza, J.A.; Fernandez, I.; Alvareza, P.G.; Gandaraa, C.J.L. A dipyrromethane-based diphosphane-germylene as precursor to tetrahedral copper(I) and T-shaped silver(I) and gold(I) PGeP pincer complexes. Dalton Trans. 2019, 48, 13273-13280. [CrossRef]

30. Hamamci, S.; Yilmaz, V.T.; Harrison, W.T.A. Silver(I)-Saccharinato Complexes with 2-(Aminomethyl)pyridine and 2-(2-

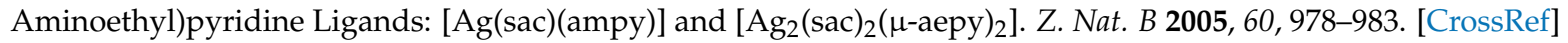

31. Soliman, S.M.; Elsilk, S.E. Synthesis, X-ray structure, DFT and antimicrobial studies of Ag(I) complexes with nicotinic acid derivatives. J. Photochem. Photobiol. B 2018, 187, 48-53. [CrossRef]

32. Infrared Absorption Bands of Carboxylate. Available online: https://www.911metallurgist.com/ir-infrared-absorption-bandscarboxylate/ (accessed on 7 February 2022).

33. Otero, V.; Sanches, D.; Montagner, C.; Vilarigues, M.; Carlyle, L.; Lopes, J.A.; Melo, M.J. Characterisation of metal carboxylates by Raman and infrared spectroscopy in works of art. J. Raman Spectrosc. 2014, 45, 1197-1206. [CrossRef]

34. Masoud, M.S.; Ali, A.E.; Elasala, G.S.; Elwardany, R.E. Structural and thermal studies on some morpholine complexes. J. Mol. Struct. 2019, 1175, 648-662. [CrossRef]

35. Khlobystov, A.N.; Blake, A.J.; Champness, N.R.; Lemenovskii, D.A.; Majouga, A.G.; Zyk, N.V.; Schröder, M. Supramolecular design of one-dimensional coordination polymers based on silver(I) complexes of aromatic nitrogen-donor ligands. Coord. Chem. Rev. 2001, 222, 155-192. [CrossRef]

36. Nomiya, K.; Yoshizawa, A.; Tsukagoshi, K.; Kasuga, N.C.; Hirakawa, S.; Watanabe, J. Synthesis and structural characterization of silver(I), aluminium(III) and cobalt(II) complexes with 4-isopropyltropolone (hinokitiol) showing noteworthy biological activities. Action of silver(I)-oxygen bonding complexes on the antimicrobial activities. J. Inorg. Biochem. 2004, 98, 46-60. [CrossRef] [PubMed]

37. Ahmad, S.; Isab, A.A.; Ali, S.; Al-Arfaj, A.R. Perspectives in bioinorganic chemistry of some metal based therapeutic agents. Polyhedron 2006, 25, 1633-1645. [CrossRef]

38. Al-Zamil, N.O.; Al-Sadham, K.A.; Isab, A.A.; Wazer, M.I.M.; Al-Arfaj, A.R.A. Silver(I) complexes of imidazolidine-2-thione and triphenylphosphines: Solid-state, solution NMR and antimicrobial activity studies. Spectroscopy 2007, 21, 61-67. [CrossRef]

39. Tuszkanow, M.P.; Grabowski, T.; Daszkiewicz, M.; Wietrzyk, J.; Filip, B.; Maclejewska, G.; Golonka, M.C. Silver(I) complexes with hydantoins and allantoin Synthesis, crystal and molecular structure, cytotoxicity and pharmacokinetics. J. Inorg. Biochem. 2011, 105, 17-22. [CrossRef]

40. Tan, X.J.; Liu, H.Z.; Ye, C.Z.; Lou, J.F.; Liu, Y.; Xing, D.X.; Li, S.P.; Liu, S.L.; Song, L.Z. Synthesis, characterization and in vitro cytotoxic properties of new silver(I) complexes of two novel Schiff bases derived from thiazole and pyrazine. Polyhedron 2014, 71, 119. [CrossRef]

41. Zhu, H.-L.; Zhang, X.-M.; Liu, X.-Y.; Wang, X.-J.; Liu, G.-F.; Usman, A.; Fun, H.-K. Clear Ag-Ag bonds in three silver(I) carboxylate complexes with high cytotoxicity properties. Inorg. Chem. Commun. 2003, 6, 1113-1116. [CrossRef]

42. Liu, X.Y.; Zhu, H.L. Strong silver-silver interactions in three silver(I) carboxylate complexes with high cytotoxicity properties. Synth. React. Inorg. Met. Org. Nano Met. Chem. 2005, 35, 325-332. [CrossRef]

43. Santini, C.; Pellei, M.; Papini, G.; Morresi, B.; Galassi, R.; Ricci, S.; Tisato, F.; Porchia, M.; Rigobello, M.P.; Gandin, V.; et al. In vitro antitumour activity of water soluble $\mathrm{Cu}(\mathrm{I}), \mathrm{Ag}(\mathrm{I})$ and $\mathrm{Au}(\mathrm{I})$ complexes supported by hydrophilic alkyl phosphine ligands. J. Inorg. Biochem. 2011, 105, 232-240. [CrossRef]

44. McKeage, M.J.; Papathanasiou, P.; Salem, G.; Sjaarda, A.; Swiegers, G.F.; Waring, P.; Wild, S.B. Antitumor activity of gold(I), silver(I) and copper(I) complexes containing chiral tertiary phosphines. Met. Based Drugs. 1998, 5, 217-223. [CrossRef]

45. He, J.; Wang, Q.K.; Li, X.J.; Pu, S.P. Synthesis, Characterization and Antitumor Activities of Cis- chlorogenic acid[(1R,2R)-1,2cyclohexanediamine] Platinum(II). Adv. Mater. Res. 2021, 884, 593-597. [CrossRef]

46. Ali, K.A.; Abd-Elzaher, M.M.; Mahmoud, K. Synthesis and Anticancer Properties of Silver(I) Complexes Containing 2,6Bis(substituted)pyridine Derivatives. Int. J. Med. Chem. 2013, 2013, 256836. [CrossRef] [PubMed] 